\title{
Protective and adaptive responses by antioxidant flavonoids
}

Citation for published version (APA):

Lemmens, K. J. A. (2015). Protective and adaptive responses by antioxidant flavonoids. [Doctoral Thesis, Maastricht University]. Uitgeverij BOXPress. https://doi.org/10.26481/dis.20150415kl

Document status and date:

Published: 01/01/2015

DOI:

$10.26481 /$ dis.20150415kl

Document Version:

Publisher's PDF, also known as Version of record

\section{Please check the document version of this publication:}

- A submitted manuscript is the version of the article upon submission and before peer-review. There can be important differences between the submitted version and the official published version of record.

People interested in the research are advised to contact the author for the final version of the publication, or visit the DOI to the publisher's website.

- The final author version and the galley proof are versions of the publication after peer review.

- The final published version features the final layout of the paper including the volume, issue and page numbers.

Link to publication

\footnotetext{
General rights rights.

- You may freely distribute the URL identifying the publication in the public portal. please follow below link for the End User Agreement:

www.umlib.nl/taverne-license

Take down policy

If you believe that this document breaches copyright please contact us at:

repository@maastrichtuniversity.nl

providing details and we will investigate your claim.
}

Copyright and moral rights for the publications made accessible in the public portal are retained by the authors and/or other copyright owners and it is a condition of accessing publications that users recognise and abide by the legal requirements associated with these

- Users may download and print one copy of any publication from the public portal for the purpose of private study or research.

- You may not further distribute the material or use it for any profit-making activity or commercial gain

If the publication is distributed under the terms of Article $25 \mathrm{fa}$ of the Dutch Copyright Act, indicated by the "Taverne" license above, 


\section{Stellingen}

behorende bij het proefschrift

\section{Protective and adaptive responses by antioxidant flavonoids}

\section{Kristien Lemmens}

Maastricht, 15 april 2015

1. Het direct antioxidant effect van monoHER is van fysiologisch belang. (dit proefschrift)

2. Een kleine verandering in structuur heeft een grote invloed op de thiolreactiviteit van een flavonoïd. (dit proefschrift)

3. Juist in cellen die blootgesteld zijn aan oxidatieve stress, stimuleert monoHER het antioxidant-beschermingssysteem. (dit proefschrift)

4. De meest voorkomende metaboliet van monoHER in muizen draagt weinig bij aan de antioxidant activiteit van monoHER. (dit proefschrift)

5. Alleen als monoHER een directe antioxidantwerking heeft, heeft het ook een indirecte antioxidantwerking. (dit proefschrift)

6. Toxicologie geeft inzichten in gezondheid.

7. Hoe meer je te weten komt, hoe meer je beseft hoe weinig je weet.

8. De beste ingevingen komen als je met iets anders bezig bent.

9. Soms kun je de middenweg beter weglaten om met drie begeleiders overeenstemming te bereiken.

10. Als je ergens goed in bent, betekent het nog niet dat je dat ook moet doen.

11. Ook een wijze uil begint als uilskuiken. 